\title{
The Practice of Shariah-Compliant Hotel in Malaysia
}

\author{
Nor Zafir Md Salleh, Abu Bakar Abdul Hamid, Noor Hazarina Hashim, and Siti Zaleha Omain
}

\begin{abstract}
Over the past one decade, there has been an increasing focus on Islamic products and services research such as Halal food and Islamic banking. Halal revolution has created increasing awareness among Muslim to consume Halal product or Shariah-compliant services. In responding to this development, hotels created innovative services for Muslim guests called Shariah-compliant hotel $(\mathrm{SCH})$. However, there is lack of research on the characteristics, and implementation of SCH has been carried out in the hotel industry. Therefore, the purpose of this paper is to understand the practice of $\mathrm{SCH}$ in Malaysia. Diffusion of innovation (DOI) theory is utilised to investigate the issues of adoption and implementation of SCH. The preliminary study uses in-depth, open-ended interviews through purposive sampling. Interviews were recorded, transcribed, and evaluated based on thematic analysis to understand the practice. The study found three issues in implementing SCH, such as the uncertainties of government regulation, difficulties to meet Halal standard, and absence of SCH standard. Along with this, two Malaysian Standards (MS1900:2005 \&MS1500:2004) have been identified and strongly suggested to be used as a tool in the $\mathrm{SCH}$ practice.
\end{abstract}

Index Terms-Islamic hotel, hospitality, diffusion of innovation.

\section{INTRODUCTION}

Developing nations have taken advantage of rapid development of tourism industry in terms of positive economic consequences like income and job creation, foreign exchange earnings, and inward investment [1]. In Malaysia, tourism is becoming the top foreign exchange earner next to manufacturing [2]. In the future, tourism will be the biggest foreign exchange earner that will surpass the manufacturing sector. The expansion of the tourism industry, through its linkages, has contributed to growth in other related activities, particularly food and beverage, accommodation, entertainment, and shopping [3].

Accommodation sector is one of the most important sectors that support the tourism industry, which has grown steadily in parallel with the Malaysian hospitality industry. The literature identified several factors that influence the rapid development of hospitality industry in Malaysia, such as the availability of low-cost courier, low cost of traveling, increase in the supply of hotel rooms, hotel innovativeness, and increase in the number of tourist arrival, which foster the business of hotels [4], [5]. As a result, there are new hotels being built, resulting in oversupply of rooms. For instance, the occupancy rate for hotels in Malaysia is considered low, which is 60 per cent in big cities, such as Kuala Lumpur, and

Manuscript received September 15, 2013; revised October 25, 2013.

The authors are with Business Management Department, Faculty of Management, UniversitiTeknologi Malaysia, Skudai, 81310 Johor, Malaysia (email: zafir@utm.my or nozafira@yahoo.com).
50 per cent in small cities, such as Ipoh [6]. Therefore, to remain viable in the intense competition environment, hotels could apply creative innovation in service and sophisticated marketing strategies to meet the increasing and complex demand of local and foreign travelers [7]. Shariah-compliant hotel (hereafter $\mathrm{SCH}$ ) is a new innovative and creative service found in the hotel industry. Recently, the existence of Islamic hospitality or Shariah hotel is being built beyond Gulf countries in Asia [8]. This development can be traced in Malaysia and Indonesia where Muslim residents are the majority population, but not in countries where Muslim residents are the minority, such as Thailand, Philippines, and China [9], [10]. Nonetheless, Zailani et al. (2011) contended that there is no comprehensive study found on Halal or Shariah-compliant practices in Malaysian hospitality industry. Despite the growing demand on Halal market in the tourism industry, there is insufficient knowledge on the practice of Halal or Shariah compliance of hotels in Malaysia [11]. As such, this study will add significantly on the literature of Shariah-compliant hotel concept in Malaysia.

The purpose of this paper is to provide an understanding of $\mathrm{SCH}$ practices by Malaysian hotels. Using purposive sampling, this study conducted in-depth interviews with the experts in the hotel industry in Malaysia, including government officials, hoteliers, and hotel associations. The first section will describe the Muslim tourists' needs, $\mathrm{SCH}$ development, and SCH concept and its attributes. The succeeding sections will discuss the research methodology, discussion, and conclusion of this study.

\section{LITERATURE REVIEW}

\section{A. Shariah-Compliant Hotel Development}

The needs of Muslim tourists during traveling are according to the Pillars of Islam and the Article of Iman. This is because a Muslim has to act according to and believe in the Pillars of Islam and the Article of Iman; otherwise, it is considered a sin. As Islam is a way of life, a Muslim is required to perform the religious duties everywhere [12]. For instance, a Muslim traveler needs to perform his or her religious routine such as prayer (Salaah) five times a day and consume Halal food while traveling. This calls for concern among hoteliers to provide such facilities that enable Muslim travelers to perform their regular religious duties. For example, the hotel can put up sign on the direction of Mecca in the hotel room, offer prayer mat upon check-in, and provide Halal food and information on prayer time [13]. In the view of some experts, the analysis of religious needs is vital in providing hotel services and designing a marketing strategy [14]-[16]. Thus, it is worthwhile for hotel managers to understand how Muslim tourists should perform their 
religious routines to satisfy their needs while traveling. This understanding will enhance the design of new hotel service to the targeted guests.

\section{B. Shariah-Compliant Hotel Development}

The growing demand for products and services that comply with Islamic law or Shariah law is obvious and substantial in finances and food both in the past and at present; the trend is moving toward the traveling industry [17], [18]. Religion is known as a stable factor that influences consumer buying behavior, resulting in more demand on religious-related product and services [15]. In the hotel industry, there is growing demand in hotels that offer facilities and rooms that follow the Shariah law [19], [20].

Several factors contributed to the growth of Shariah-compliant hotels. These include the following: 1) The increase efforts to develop tourism industry among Organization of Islamic Conference (OIC) countries enhanced travelling within its members. 2) The attractiveness of high spending and lucrative market of Middle East (ME) travelers sparks interest of many hotels to provide Islamic services to fulfill their needs. 3) Stringent security measure and difficulties to get visa approval in the West shifted ME travelers to the East and increased the demand on Islamic services in the tourism industry. 4) Halal revolution has created high awareness among Muslim travelers regarding their religious needs; therefore, it creates an opportunity to serve the Muslim tourists' untapped needs. 5) The growth of Islamic banking and finance increased investors' interest to invest in Halal products and services such as SCH. 6) The fast-growing Muslim market is estimated at USD $\$ 500$ billion annually, and the Halal market worth USD\$2.1 trillion in the world increased the popularity and visibility of the SCH [11], [21]-[24].

The prospect for the development of the $\mathrm{SCH}$ concept looks bright in the view of some experts, although its development is slow [22]. Many international chain hotels operating in the Middle East, such as the Landmark Hotel Group and The Serai Group, had plans to open SCH as early as 2006; however, the progress is delayed because many parts of the world were affected by economic downturn in 2008 [8]. However, according to many researchers the main factor that has an impact on $\mathrm{SCH}$ development is the absence of SCH standard and requirements [19]-[21], [23], [25]. As argued by Henderson (2010), Rosenberg and Choufany (2009), and Birchall (2009), without the established standard of $\mathrm{SCH}$, the practice of $\mathrm{SCH}$ appears different from one hotel to another. For example, two Dubai-based Shariah-compliant hotels practice different $\mathrm{SCH}$ and provide different levels of Islamic services. For Almulla Hospitality, their Islamic services are more extensive, which include no alcohol, adult entertainment, and gambling; they provide Halal food, qiblah direction, prayer time, and separate recreation facilities for men and women. In contrast, Rayhaan Hotels and Resorts provide limited services to Muslim guests such as no serving of alcohol in the hotel and separate recreation areas for women and men [25].

The onion diagram by Solomon et al. (2008) provides a useful framework to show the different levels of Islamic services provided by the hotels [26]. The onion diagram describes the three distinct layers of service that consists of the core, actual, and augmented product. Each layer adds more Islamic values in terms of services offered by the hotels. For example, the core service consists of the primary benefits to hotel guests such as a clean room and Halal food. The actual service includes more Islamic services than the core services, such as prayer time, separate recreation facilities for women and men, prayer room, and mosque location. Lastly, the augmented service comprises extensive Islamic services, as listed in Fig. 1.

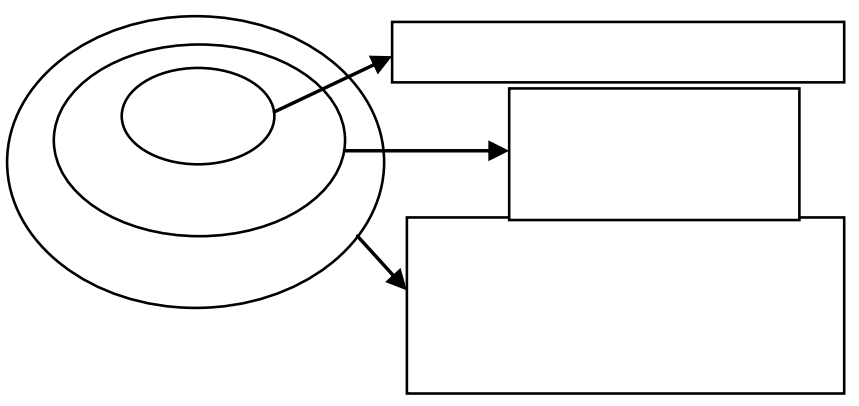

Fig. 1. Levels of Islamic hotel services Source: Adopted from Solomon, et al.(2008)

\section{The Concept of $\mathrm{SCH}$}

Islamic hospitality is embedded in Islamic religion, culture, and experience because Islam is a way of life. It is extensively practiced in Middle East where Islam is originated. It offers traditional principles and custom for Muslim travelers [24]. The concept of SCH has evolved from fulfilling religious needs to lifestyle option with emphasis on family and health [27]. In the Middle East, many hotels offer basic Islamic services, and the trend tends to shift to fuller services. In addition, the target market is extended to non-Muslims by striking on the selling proposition of family and health-oriented concept [23]. However, there is lack of empirical research and article written on the concept of SCH that acknowledges the underdeveloped concept of SCH [19], [22], [28].

The current literature on SCH concept has been descriptive in nature because there is lack of empirical data available related to the Shariah-compliant hotel [19], [23]. In 1982, Din had made an early attempt to lay out the $\mathrm{SCH}$ attributes in a review on Islamic Tourism [29]. The author suggested that hotels could provide prayer mat, Quran, and prayer beads; show the sign of Kiblah for the Muslim guest to perform a daily prayer; should ban alcohol; provide different utensils for Muslim customers; and be sensitive to the guest's religion by providing Quran for a Muslim or Bible for a Christian. Unmarried couples are not allowed to check in, which means that the hotel should request the marriage certificate upon checking in, and lastly, the hotel should not allow any drug-dealing activities within its premises [29].

In the view of marketing activities, Hashim et al. (2006) believed that destination marketing organizations and hotels could improve their marketing efforts by presenting more Islamic information on their Web sites. Rosenberg and Choufany (2009) focused on the major aspect of hotel operation where they divided the guidelines into three important categories in hotel operations: operations, design and interiors, and financial. However, the guidelines seem to neglect the daily needs of Muslim travelers, which is to 
perform daily prayer. Next, Stephenson et al. (2010) provided extensive guidelines, focused more on the room interior in accordance to the Muslim needs, and included the Shariah-compliant management perspective where hotel owners should contribute a portion of the revenue in accordance to the zakat principles [30]. The guideline overlooks the entertainment and recreational facilities in accordance to the Shariah law, which are important to meet the needs of hotel guests. Finally, Henderson constructed the attributes of $\mathrm{SCH}$, but it is extremely general and overlooks the management element in SCH. Table I shows the proposed $\mathrm{SCH}$ guidelines.

\begin{tabular}{|l|l|}
\hline \multicolumn{1}{|c|}{ TABLE I: THE SUMMARY OF SCH GUIDELINES } \\
\hline Din (1982) & \begin{tabular}{l}
\multicolumn{1}{c|}{ Proposed guidelines on SCH } \\
Basic Muslim needs (eg, provide prayer mat, \\
Quran, prayer beads, and sign of Kiblah; should \\
ban alcohol; provide different utensils for Muslim \\
customers and Quran; unmarried couples are not \\
allowed to check in; and no drug-dealing \\
activities).
\end{tabular} \\
\hline $\begin{array}{l}\text { Hashim,et } \\
\text { al.(2006) }\end{array}$ & $\begin{array}{l}\text { Present more Islamic information on hotel Web } \\
\text { sites (eg, location of mosque and Halal food to be } \\
\text { made available at the concierge desks and Web } \\
\text { sites). }\end{array}$ \\
\hline $\begin{array}{l}\text { Rosenberg and } \\
\text { Choufany (2009) }\end{array}$ & $\begin{array}{l}\text { Focus on operations, design and interiors, and } \\
\text { financial (eg, no picture of human part as display). }\end{array}$ \\
\hline $\begin{array}{l}\text { Stephenson et al. } \\
\text { (2010) }\end{array}$ & $\begin{array}{l}\text { Narrowly focused on the interior design of the } \\
\text { room and Islamic financial management (eg, } \\
\text { zakat). }\end{array}$ \\
\hline Henderson (2010) & $\begin{array}{l}\text { General guidelines for SCH (eg, conservative staff } \\
\text { dress, all-female floors, guest dress code). }\end{array}$ \\
\hline $\begin{array}{l}\text { Source: (Din, 1982; Hashim, et al., 2006; Henderson, 2010; Rosenberg and } \\
\text { Choufany, 2009b; Stephenson, et al., 2010) }\end{array}$
\end{tabular}

The literature provides several proposals on guidelines and constructs of SCH; however, the agreement on a common set of construct or guideline does not appear to exist [19], [23]. Most authors provide guidelines that narrowly focused on Shariah-compliant services offered by the hotels, thus failing to see the actual needs of Muslim guests and ignoring the management aspect of $\mathrm{SCH}$. This may be due to the scope of the research, which is focused only on the Middle East, where Islam is originated and Islamic hospitality is widely practiced. Nevertheless, the practice of $\mathrm{SCH}$ in Asia where the majority of the population are Muslim has yet to be uncovered [23]. Therefore, it is important to understand what has been practiced by Malaysian hotels in terms of Islamic services to develop a better insight on this matter. Thus, this research will provide in-depth information on the practice of $\mathrm{SCH}$ in the Muslim-populated country. This paper reports the initial study of $\mathrm{SCH}$ practices and contributes to the Malaysian hospitality industry by providing some information on the implementation of $\mathrm{SCH}$ by Malaysian hotels.

\section{SCH as a Service Innovation}

In today's globally competitive tourism sector, hotels adopt and implement innovation to stay competitive and sustain market share [31]. It has been proven through previous studies that innovation could be a tool to improve service quality, hotel reputation, and competitive advantage in hotel industry [32], [33]. In this study, SCH is categorized as service innovation because $\mathrm{SCH}$ is a new service concept adopted and implemented by hotels in Malaysia. In addition, the adoption of $\mathrm{SCH}$ is an identifying factor for Muslim tourists to stay at the hotel [34]. In addition, Rogers (2003) define innovation as any practice, new idea, or object that is new to an organization. Despite the broad definition provided by Rogers (2003), scholars found it suitable to be applied in the service industry such as hotels [35], [36]. Therefore, SCH is an innovation as it puts forward new idea and practice to the Malaysian hospitality industry.

The theoretical premises of this study are based on theories of the diffusion of innovation (DOI) [37]. This study emphasizes the issues of adopting $\mathrm{SCH}$, which involves both external and internal factors [38]. The internal factors include firm size, firm profitability, innovation champions, and organizational attributes [39], whereas the external factors include change agent, communication, and social system. These variables are important to influence the adoption of an innovation. However, no study has been conducted to elaborate the identified factors above in adoption of service innovation. Therefore, this study is important in understanding the service innovation adoption among hotels in Malaysia.

\section{RESEARCH METHODOLOGY}

This preliminary study adopted in-depth, open-ended interviews through purposive sampling to understand the practice and generate a set of SCH attributes in Malaysia. Snowball sampling technique was applied to determine the potential interviewee as the population is small and specialized. The interview process began with two experts in Malaysia's hospitality industry who later recommended other experts to provide more information regarding the subject matter. A total of 6 respondents were interviewed, and the background of respondents is presented in Table II. The interviews were recorded, transcribed, and categorized within a week, based on interview questions. The interview questions are developed based on the SCH literature and DOI theory. Categories based on relevant themes were established after examination of the data. The data were sorted into categories using key words as codes. The respondents were asked about their opinion on issues regarding the $\mathrm{SCH}$ implementation in Malaysia. Several issues were brought up and discussed in the next section.

\section{DISCUSSION}

From the interview conducted, several issues were highlighted by the respondents including the government regulation, application to obtain Halal certificate, and Shariah-compliant hotel standard. Recently, the Malaysian government enforced the regulation that only hotels with Halal certificate for restaurant can cater to the government functions [11]. The encouragement for hotels to obtain Halal certificate for its restaurant or food and beverage outlet is seen as a good one at the appropriate time. However, the effect of this new regulation is tremendous as many hotels were forced to or would like to obtain Halal certificate because having their restaurant certified enables them to fulfill the requirement for some government events.

Nevertheless, majority of the respondents were uncomfortable with the short notice given because of the above regulation. One of the respondents said the following: 
"It is unfair for the government to enforce the regulation overnight because many events by government agency that have been planned months before have to be cancelled. This action is very unprofessional and effect on the hotel's income."

Because of this, it can be concluded that the government regulation creates uncertainty in the Malaysian hotel business. High uncertainty on regulation in the hotel business will affect the development of Malaysian hotels. The high uncertainty level on government policies in an industry will drive away the foreign investors and confuse local hotel operators.

\begin{tabular}{|c|c|c|c|}
\hline Interviewee & Organization & Designation & $\begin{array}{l}\text { Background of the } \\
\text { respondents }\end{array}$ \\
\hline A & $\begin{array}{l}\text { Hotel } \\
\text { Association }\end{array}$ & $\begin{array}{l}\text { Senior } \\
\text { Executive of } \\
\text { Finance }\end{array}$ & $\begin{array}{l}\text { - Representative for } \\
\text { many government-led } \\
\text { committees to } \\
\text { improvise hotel } \\
\text { industry. } \\
\text { - Association represents } \\
515 \text { hotel members } \\
\text { throughout Malaysia. } \\
\text { - The association acts as } \\
\text { a voice of the industry, } \\
\text { working as one body to } \\
\text { promote, protect, } \\
\text { represent, and advance } \\
\text { the interest of its } \\
\text { members. }\end{array}$ \\
\hline B & $\begin{array}{l}\text { Hotel Owners } \\
\text { Association }\end{array}$ & $\begin{array}{l}\text { Executive } \\
\text { Director }\end{array}$ & $\begin{array}{l}\text { - The association was } \\
\text { established since } 1998 \text {. } \\
\text { - Represents } 62 \text { hotel } \\
\text { owners in Malaysia. } \\
\text { - Representing the } \\
\text { interests of members in } \\
\text { safeguarding their } \\
\text { return on investments. } \\
\text { - Promote the } \\
\text { development of hotel } \\
\text { industry especially in } \\
\text { dealing with } \\
\text { authorities on issues } \\
\text { affecting the industry. }\end{array}$ \\
\hline $\mathrm{C}$ & $\begin{array}{l}\text { Ministry of } \\
\text { Tourism, } \\
\text { Policy, } \\
\text { Planning, and } \\
\text { International } \\
\text { Affairs Division }\end{array}$ & $\begin{array}{l}\text { Assistant } \\
\text { Secretary }\end{array}$ & $\begin{array}{l}\text { - Responsible in } \\
\text { planning and } \\
\text { development of } \\
\text { Islamic Tourism in } \\
\text { Malaysia. } \\
\text { - Committee member for } \\
\text { hotel rating evaluation. }\end{array}$ \\
\hline $\mathrm{D}$ & $\begin{array}{l}\text { Ministry of } \\
\text { Tourism, } \\
\text { Licensing } \\
\text { Division }\end{array}$ & $\begin{array}{l}\text { Assistant } \\
\text { Secretary }\end{array}$ & $\begin{array}{l}\text { - Responsible on hotel } \\
\text { ratings and tour } \\
\text { operator operations. } \\
\text { - Committee member for } \\
\text { hotel ratings } \\
\text { evaluation. }\end{array}$ \\
\hline E & $\begin{array}{l}\text { Hotel A } \\
4 \text { stars }\end{array}$ & $\begin{array}{l}\text { Shariah } \\
\text { Compliance } \\
\text { Executive }\end{array}$ & $\begin{array}{l}\text { - Assists in preparing } \\
\text { and maintaining MS } \\
\text { 1500:2009* and MS } \\
\text { 1900:2005**. } \\
\text { - Internal Auditor for the } \\
\text { above standard. } \\
\text { - Person in charge in } \\
\text { handling both } \\
\text { Malaysian Standards. }\end{array}$ \\
\hline $\mathrm{F}$ & $\begin{array}{l}\text { Hotel B } \\
3 \text { stars }\end{array}$ & $\begin{array}{l}\text { Shariah } \\
\text { Compliance } \\
\text { Committee/ } \\
\text { Purchasing } \\
\text { Executive }\end{array}$ & $\begin{array}{l}\text { Assists in preparing } \\
\text { and maintaining MS } \\
\text { 1500:2009*. } \\
\text { - Internal Auditor for the } \\
\text { above Malaysian } \\
\text { Standard. }\end{array}$ \\
\hline
\end{tabular}

The next issue is the slow process in obtaining Halal certificate by JAKIM, a body which is responsible for granting Halal certification in Malaysia, which lowers the motivation of hotels to obtain such certification. Moreover, the requirements for restaurants to be Halal certified are not good to the hospitality industry, resulting in application difficulties for hotels. Majority of the respondents have the same opinion that JAKIM needs to simplify the process and requirements in obtaining Halal certification. Respondents A and B highlighted that, currently, JAKIM is addressing this issues, and continuous discussion among stakeholders of hospitality industry is going on to improve the Halal application system. The improvement of obtaining Halal certificate will help boost Malaysia's image as one of the top Muslim tourist destinations.

The absence of Shariah-compliant standard is another important issue highlighted by the respondents. Respondent B emphasized the following:

"Many hotels claimed that they are SCH without understanding the term Shariah itself. They promote $\mathrm{SCH}$ as their marketing strategy and not as the concept of the hotels. The SCH concept should be developed based on the Islamic perspective of doing business and not as a tag line only."

Another respondent explained the following:

"In our hotel, the Shariah-compliant concept is applied based on the MS1500:2009, which is Malaysian Standard of Halal Food Production, Preparation, Handling, and Storage (Halal certification by JAKIM), and MS1900:2005, which is Malaysian Standard for Quality Management System Requirements from Islamic Perspectives in running the hotel."

In contrast, respondent $\mathrm{E}$ mentioned that

“...the Shariah-compliant concept is only applicable in the restaurant."

This shows that many versions of $\mathrm{SCH}$ practices exist in Malaysian hotel operations. As discussed earlier, there are varied $\mathrm{SCH}$ practices occuring in the Middle East that may confuse some hotels in the implementation of SCH [25], [40] The delay in $\mathrm{SCH}$ development has an effect on the satisfaction of Muslim guests. Thus, it is timely for the government to develop a standard for $\mathrm{SCH}$, which will encourage more hotels to implement it and meet the needs of Muslim tourists.

All of the respondents highlighted that the application of MS1500:2009, which is the Malaysian Standard of Halal Food Production, Preparation, Handling, and Storage (Halal certification by JAKIM), could be used as a tool to apply $\mathrm{SCH}$ into practice. In addition, one respondent suggested that the MS1900:2005, which is the Malaysian Standard for Quality Management System Requirements from Islamic Perspectives, could be adopted in implementing SCH in hotel operations. Thus, the development of the SCH model in Malaysia should be based on the Muslim's needs and include several standards, such as the MS1500:2009 and MS1900:2005, as mentioned previously. 


\section{CONCLUSION AND RECOMMENDATION}

The existence of the universal standard of $\mathrm{SCH}$ is important to encourage more hotels in Malaysia to seriously adopt the SCH. The benefits of SCH are many, one of which is that it could be a competitive advantage for the hotel because the demand for Islamic goods and services are increasing. In addition, the influx of Middle East tourists to Malaysia provides immense opportunities for SCH hotels to be able to attract these tourists, enabling them to increase their profits. As mentioned earlier, the Middle East tourists are a lucrative market because they spend more than other tourists [8].

Nevertheless, the attractiveness of $\mathrm{SCH}$ has to be balanced with the current market of Malaysian hotels. Because Middle East tourists are not the only market to be served, hoteliers need to be very careful in implementing $\mathrm{SCH}$ in their operation so as not to affect their financial gain. It is admitted that the non-Muslim market contributes large profit to the hotel business. Therefore, the application of $\mathrm{SCH}$ needs a careful consideration in hotels operating in a multiracial country like Malaysia. Future research may need to address this issue from the perspective of profit gain and innovation services addressing different religious needs in applying $\mathrm{SCH}$ in Malaysia.

As a conclusion, this paper identified issues pertaining to the practice of service innovation such as $\mathrm{SCH}$. The external factor such as the role of change agent has been identified as one of the major factors for a hotel to adopt SCH. In addition, unclear SCH characteristic (eg. absence of Shariah-compliant standard for hotels) puzzled many hoteliers and disrupted the process for hotels to adopt it.

\section{REFERENCES}

[1] M. A. Sadi and J. C. Henderson, "Tourism in Saudi Arabia and its future development," Journal of Business and Economics, vol. 11, pp. 94-111, 2005.

[2] Malaysia Budget. (2009). [Online]. Available: http://www.pmo.gov.my

[3] W. C. Poon et al., "Are travellers satisfied with Malaysian hotels?" International Journal of Contemporary Hospitality Mangement, vol.17, pp. 11, 2005.

[4] R. A.Fraser, M. S. M. Zahari, Z. Othman, and S. Radzi, "Hospitality industry careers: Analysis on students interest based on different location of upbringing and secondary school background." presented at the 5th Tourism Educators Conference on Tourism and Hospitality, The New Paradigm, 2007.

[5] Tenth Malaysian Plan. (2010) [Online]. Available: http://www.epu.gov.my,

[6] J. Lahap, G. B. O'Mahony, and J. Sillitoe, "Developing a service delivery improvement model for the Malaysian hotel sector," presented at the Transformation and Modernisation in Tourism: Hospitality and Gastronomy, 2010.

[7] L. L. Berry, V. Shankar, J. T. Parish, S. Cadwallader, and T. Dotzel, "Creating new markets through service innovation," MIT Sloan Management Review, pp. 56-63, 2006.

[8] C.Tarrant, "Middle East hotel gusts express high interest in sharia compliant hotels. United Kingdom," BDRC, 2010.

[9] Anonymous. (2011). [Online]. Available: http:/www.com. dinarstandard

[10] G. Lee, "Manila hotel 1st to get halal certificate," Manila Bulletin, 2010.

[11] S. Zailani, A. Omar, and S. Kopeng, "An exploratory study on the factors influence the non-compliance to Halal among hoteliers in Malaysia," International Business Management, vol. 5, no. 1, pp.1-12, 2011.

[12] M. Begg. (1997). Islam and travelling. [Online]. Available: http://www.islamiccentre.org

[13] N. H. Hashim, J. Murphy, and N. Mohammad, "Tourism and Islam: Understanding and embracing opportunities," From the Experts, 2006.
[14] N. Delener, "The effects of religious factors on perceived risk in durable good purchase decisions," The Journal of Consumer Marketing, vol. 7, no. 3, pp. 27-38, 1990.

[15] M. Nazlidaand D. Mizerski, "The constructs mediating religions' influence on buyers and consumers," Journal of Islamic Marketing, vol. 1, pp. 124-135, 2010.

[16] A. Weidenfeld, Religious needs in the hospitality industry," Tourism and Hospitality Research, vol. 6, no. 2, pp. 143-159, 2005.

[17] J. Abdullah. (2010). Halal and Shariah compliant are they processes or values. [Online]. Available: http://www.dailybaraka.eu

[18] Z. Sulong, "Syariah-compliant: Bukan di dindingtetapi di hati," Harakah Daily, 2010.

[19] P. Rosenberg and H. M. Choufany, "Spiritual lodging- the Sharia-compliant hotel concept," 4Hoteliers, 2009.

[20] R. Siddiqui, "Opinion: Shariah compliant hotels," Halal Focus, 2011.

[21] I. A. Hamid, "Islamic compliance in hotel and restaurant business," presented at the Asia-Euro Conference: Transformation and modernization in tourism, hospitality and gastronomy, 2010.

[22] J. C. Henderson, "Islamic tourism reviewed,"Tourism Recreation Research, vol. 34, no. 2, pp. 207-211, 2009.

[23] J. C. Henderson, "Sharia-compliant hotels," Tourism and Hopitality Research, vol. 10, no. 3, pp. 246-254, 2010.

[24] L. Kaaki, "A halal environment: Demand for Islamic hotels on the rise," Arab News, 2008.

[25] L. Birchall. (2009). Laying down sharia law. Hotelier Middle East. [Online]. Available: http://www.hoteliermiddleeast.com

[26] M. R. Solomon, G. W. Marshall, and E. W. Stuart, Marketing Real People, Real Choices, Upper Saddle River, New Jersey: Pearson Education, 2008.

[27] Anonymous, "Demand for Shariah-compliant hotels rising," Emirates 24/7, 2009.

[28] G. Wilkinson, "Dry hotels - old hat or new fad?" Arabian Business.com., 2007.

[29] H. K. Din, "Tourism in Malaysia: Competing needs in the plural society," Annals of Tourism Research, vol. 9, pp. 453-480, 1982.

[30] M. L. Stephenson, K. A. Russel, and D. Edgar, "Islamic hospitality in the UAE: indigenization of products and human capital," Journal of Islamic Marketing, vol. 1, no. 1, pp. 9-24, 2010.

[31] F. O. Sintes, and J. Mattson, "Innovation behaviour in the hotel industry," The International Journal of Management Science, vol. 37, pp. 380-394, 2009.

[32] F. O. Sintes, R. C. Cladera, and E. M. Ros, "Innovation activity in the hotel industry: Evidence from Balearic Islands," Tourism Management, vol. 26, pp.851-865, 2005.

[33] M. Ottenbatcher, "New service development in the hospitality industry: An exploratory study," presented at the ANZMAC, 2001.

[34] A. M. Hjalager, "A review of innovation research in tourism,"Tourism Management, vol. 31, pp. 1-12, 2010.

[35] K. J. Klien and J. S. Sorra, "The challenge of innovation implementation," Academy of Management Review, vol.21, no. 4, pp. 1055-1080, 1996.

[36] L. G. Tornatzky and K. J. Klein, "Innovation characteristics and innovation adoption-implementation,"A meta-analysis of findings, vol. 29, no. 1, pp. 28-43, 1982.

[37] E. M. Rogers, Diffusion of Innovations 5th ed. London: Free Press, 2003.

[38] S. Sisaye and J. Birnberg, "Extent and scope of diffusion and adoption of process innovations in management accounting systems," International Journal of Accounting and Information Management, vol. 18, no. 2, pp.118-139, 2009.

[39] P. Attewell, "Technology diffusion and organizational learning: the case of business computing," Organization Science, vol. 3, no. 1, pp. 1-19, 1992.

[40] M. I. Kalesar, "Developing Arab-Islamic tourism in the Middle East: An economic benefit or a cultural seclusion?" International Politics, vol. 3,2010 .

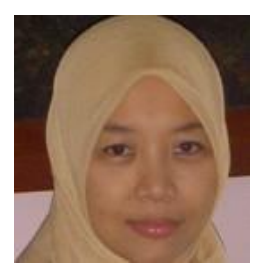

Nor Zafir Md Salleh is currently a lecturer at Faculty of Management, Universiti Teknologi Malaysia since 2003. She obtained her MBA in 2003. She has vast experience in the manufacturing industry before pursuing an academic career. She is actively attending and presenting her research finding in both international and national conferences. She has the interest in management, marketing and hospitality. 